\title{
Effects of alfalfa hay particle size in high-concentrate diets supplemented with unsaturated fat: Chewing behavior, total-tract digestibility, and milk production of dairy cows
}

\author{
A. Kahyani, ${ }^{*}$ G. R. Ghorbani, ${ }^{*}$ M. Khorvash, ${ }^{*}$ S. M. Nasrollahi, ${ }^{*}$ and K. A. Beauchemin ${ }^{1}$ \\ *Department of Animal Sciences, Isfahan University of Technology, Isfahan 84156-83111, Iran \\ †Research Centre, Agriculture and Agri-Food Canada, Lethbridge, AB, Canada T1J 4B1
}

\begin{abstract}
This study evaluated the effects of increasing the physically effective neutral detergent fiber (peNDF) intake of lactating dairy cows fed high-concentrate diets supplemented with unsaturated fat on intake, eating behavior, diet sorting, chewing activity, total-tract digestibility, and milk production and composition. Diets contained $24 \%$ alfalfa hay (AH), $16 \%$ corn silage, $58 \%$ concentrate, and $2 \%$ yellow grease [dry matter (DM) basis], and dietary peNDF content was increased by varying the particle size (PS) of the AH. Nine multiparous cows averaging $87.8 \pm 14.8 \mathrm{~d}$ in milk and weighing $653 \pm 53 \mathrm{~kg}$ were randomly assigned to a triplicate 3 $\times 3$ Latin square. During each 21 -d period, cows were offered 1 of 3 total mixed rations that varied in PS of AH: fine, medium, and long, with a geometric mean particle length of $3.00,3.57$ and $3.87 \mathrm{~mm}$, respectively. Increasing PS quadratically affected DM intake (DMI; $24.7,25.4$, and $23.7 \mathrm{~kg} / \mathrm{d}$, for fine, medium, and long, respectively), but cumulative DMI at 2, 4, and $6 \mathrm{~h}$ after feeding was similar across treatments, averaging 23.4, 35.6 and $46.4 \%$ of total DMI for the 3 time points, respectively. Increased peNDF intake did not affect feed sorting, but increased daily eating time, and eating and total chewing time per kilogram of DMI. Daily rumination time exhibited a quadratic response, with highest rumination time for the medium diet. Dietary PS had no effects on digestibility in the total tract, but we observed, for fine, medium, and long diets, quadratic responses in milk production (41.5, 43.3, and $40.4 \mathrm{~kg} / \mathrm{d}), 4 \%$ fat-corrected milk production, and milk protein yield. Milk fat content decreased linearly with increasing PS, but milk fat content and fat:protein ratio were low for all treatments, likely due to adding unsaturated fat to a diet containing a high level of nonfiber carbohydrates ( $42.2 \%$ of DM). The composition, degree of saturation, and total conjugated linoleic acid
\end{abstract}

Received December 7, 2012.

Accepted July 20, 2013.

${ }^{1}$ Corresponding author: karen.beauchemin@agr.gc.ca content of fatty acids in milk fat were not affected by the change in peNDF content of the diet. The study indicates that a moderate increase in the PS of $\mathrm{AH}$ in diets containing unsaturated fat elevates peNDF intake and increases chewing activity, DMI, milk yield and milk fat production. However, the effects of dietary PS were quadratic, with maximum DMI and milk production observed with diets supplying $24 \%$ dietary peNDF (measured as the proportion of the ration retained on sieves $>1.18 \mathrm{~mm}$ multiplied by dietary neutral detergent fiber content; DM basis).

Key words: particle size, alfalfa hay, feed sorting, unsaturated fat

\section{INTRODUCTION}

Increasing the physically effective NDF (peNDF) content of the diet increases the chewing activity of dairy cows, which is beneficial for salivary secretion and rumen function (Mertens, 1997). The peNDF content of diets can be increased by incorporating a higher proportion of forage in the diet and by increasing the particle size (PS) of forages (Yang and Beauchemin, 2007). Increased forage proportion can lower energy intake; thus, in commercial dairy operations, the peNDF content of diets is often achieved by substituting a portion of the silage with coarsely chopped hay.

The effects of PS of alfalfa hay (AH) on chewing behavior and milk production of dairy cows has been studied previously (Teimouri Yansari et al., 2004; Zebeli et al., 2007; Nasrollahi et al., 2012). Increasing the PS of AH can increase DMI, eating and rumination time, ruminal $\mathrm{pH}, \mathrm{FCM}$ production, and milk fat production, particularly when diets are low in peNDF, but the results are often inconsistent depending upon the conditions of the experiment. As direct measurements of ruminal $\mathrm{pH}$ are not always possible in intact dairy cows, the need exists to better understand the effects of forage PS on aspects of feeding behavior and other indicators of healthy rumen function.

It is not known whether increasing the PS of $\mathrm{AH}$ to increase peNDF of diets containing unsaturated fat 
would be beneficial. Cows fed diets supplemented with unsaturated fat, particularly diets that contain a high level of NFC, often experience low ruminal pH (Coomer et al., 1993). Fat supplementation of dairy cow diets can be a useful means of increasing the $\mathrm{NE}_{\mathrm{L}}$ content of the diet, but high concentrations $(\geq 25 \mathrm{~g} / 1,000 \mathrm{~g}$ of $\mathrm{DM})$ of supplemental unsaturated fat can compromise feed intake, ruminal digestion, and milk composition and production (Harvatine and Allen, 2006a,b,c). Because unsaturated fats are precursors for trans FA, specifically trans-10 C18:1, and its immediate precursor in the rumen, trans-10,cis-12 conjugated linoleic acid (CLA), low milk fat production can occur when unsaturated fats are fed to cows with low ruminal $\mathrm{pH}$ (Bauman and Griinari, 2001).

Most studies that have considered the effect of forage PS and fat supplementation of the diet have used tallow as the fat source (Grant and Weidner, 1992; Jenkins et al., 1998; Onetti et al., 2003). Thus, it remains unclear how performance and behavior of dairy cows would be influenced by moderate increases in AH PS in diets supplemented with unsaturated fat. As increasing the PS of $\mathrm{AH}$ in diets supplemented with unsaturated fat increases peNDF intake, we hypothesized that an increase in chewing activity and a reduction in milk fat depression would occur. Therefore, the objective of our experiment was to evaluate the effects of increasing AH PS on eating behavior, sorting activity, chewing activity, total-tract digestibility, and milk production of lactating dairy cows fed high-concentrate diets supplemented with unsaturated fat. Yellow grease derived from used cooking oil was the source of unsaturated fat.

\section{MATERIALS AND METHODS}

\section{Cows, Forages, and Diets}

Nine multiparous lactating Holstein dairy cows $(653$ $\pm 53 \mathrm{~kg}$ of $\mathrm{BW}$; mean $\pm \mathrm{SD}$ ) averaging $87.8 \pm 14.8$ DIM and producing $45 \pm 4 \mathrm{~kg} / \mathrm{d}$ of milk were used in the study. Cows were blocked by DIM and randomly assigned to a replicated $3 \times 3$ Latin square experimental design with 3 dietary treatments: fine, medium, and long PS achieved by incorporating AH of varying PS. Experimental periods were $21 \mathrm{~d}$ in duration, with $14 \mathrm{~d}$ for diet adaptation followed by $7 \mathrm{~d}$ for data collection. The experiment was conducted at the dairy facilities of the Lavark Research Station (Isfahan University of Technology, Isfahan, Iran). Animals were cared for according to the guidelines of the Iranian Council of Animal Care (1995) and the experiment was approved by the Institutional Animal Care Committee for Animals Used in Research.
Regrowth (second-cut) alfalfa from a single field was harvested at $50 \%$ flowering on a day without precipitation. The material was wilted and baled (small rectangular bales; average weight of $15 \mathrm{~kg}$ ). Subsequently, the bales were chopped with a forage field harvester (Golchin Trasher Hay Co., Isfahan, Iran) using theoretical chop length settings of 30 and $15 \mathrm{~mm}$ to obtain the long and medium PS treatments, respectively. To obtain the fine PS treatment, medium-chopped AH was rechopped using a threshing machine (designed to separate cereal grains from straw) with a theoretical chop length setting of $10 \mathrm{~mm}$ (Golchin Trasher Hay Co.).

Corn silage was harvested using a pull-type chopper (model 965, Claas, Omaha, NE) set to produce particles with an average theoretical chop length of 25 to $30 \mathrm{~mm}$. Corn, barley, and soybean meal were finely ground through a 4-mm screen using a hammer mill (model 5543 GEN, Isfahan Dasht, Isfahan, Iran). All diets were formulated using the Cornell Net Carbohydrate and Protein System, version 5.0 (Fox et al., 2000) to meet the requirements of a $650-\mathrm{kg}$ multiparous cow producing $45 \mathrm{~kg} / \mathrm{d}$ of milk (Table 1 ). Cows were housed in individual pens $(4 \times 4 \mathrm{~m})$ in an open-sided barn, each equipped with a manger $(1 \mathrm{~m} \times 0.5 \mathrm{~m} \times 0.4 \mathrm{~m}$; length $\times$ width $\times$ height). Cows were allowed $30 \mathrm{~min}$ of exercise 3 times daily. Diets were offered as TMR once daily at $0900 \mathrm{~h}$. Cows were fed for ad libitum intake allowing for $10 \%$ refusals, and cows had free access to water.

\section{DMI, Total-Tract Digestibility, and Milk Production}

On the last 5 consecutive days of each period, DMI was determined for each cow as the difference between TMR offered and orts weighed daily, with samples collected daily and pooled by period (and by cow for the orts) for the determination of DM and nutrient content. Additionally, samples of feces were collected directly from the rectum once daily on the last 5 consecutive days of each period and pooled (by cow and period). Fecal samples were stored at $-10^{\circ} \mathrm{C}$, pooled by period and cow, and processed for chemical analysis. Apparent total-tract digestibility was determined using acidinsoluble ash as an internal marker (Van Keulen and Young, 1977).

Cows were milked 3 times daily at 8 -h intervals (0200, $1000,1800 \mathrm{~h}$ ) in a milking parlor, with cows provided with $30 \mathrm{~min}$ of exercise time following each milking. At each milking on the last 5 consecutive days of each period, milk yield was recorded and sampled into vials containing potassium dichromate as a preservative. Milk samples were analyzed for fat, true protein, and lactose content (134 BN Foss Electric, Hillerød, Denmark). 
Table 1. Composition and nutrient content of dietary treatments with long, medium, and fine particle size achieved by incorporating alfalfa hay of varying particle size ${ }^{1}$

\begin{tabular}{|c|c|c|c|}
\hline \multirow[b]{2}{*}{ Item } & \multicolumn{3}{|c|}{ Diet } \\
\hline & Long & Medium & Fine \\
\hline \\
\hline & \multicolumn{3}{|c|}{ Alfalfa hay ${ }^{2}$} \\
\hline Long & 24.0 & & \\
\hline Medium & & 24.0 & \\
\hline Fine & & & 24.0 \\
\hline Corn silage $^{3}$ & 16.0 & 16.0 & 16.0 \\
\hline Beet pulp & 5.4 & 5.4 & 5.4 \\
\hline Ground barley & 32.0 & 32.0 & 32.0 \\
\hline Ground corn & 4.8 & 4.8 & 4.8 \\
\hline Soybean meal & 12.5 & 12.5 & 12.5 \\
\hline Yellow grease ${ }^{4}$ & 2.0 & 2.0 & 2.0 \\
\hline Fish meal & 0.8 & 0.8 & 0.8 \\
\hline Sodium bicarbonate & 1.0 & 1.0 & 1.0 \\
\hline Vitamin-mineral mix $^{5}$ & 0.4 & 0.4 & 0.4 \\
\hline Calcium carbonate & 0.7 & 0.7 & 0.7 \\
\hline Salt & 0.4 & 0.4 & 0.4 \\
\hline \multicolumn{4}{|l|}{ Chemical composition } \\
\hline DM, \% & 56.4 & 56.4 & 55.4 \\
\hline $\mathrm{OM}, \%$ of $\mathrm{DM}$ & 90.1 & 90.7 & 90.7 \\
\hline $\mathrm{CP}, \%$ of $\mathrm{DM}$ & 16.3 & 16.2 & 16.2 \\
\hline $\mathrm{NFC}{ }^{6} \%$ of DM & 42.2 & 42.2 & 42.2 \\
\hline NDF, $\%$ of DM & 32.2 & 32.2 & 32.2 \\
\hline $\mathrm{ADF}, \%$ of $\mathrm{DM}$ & 22.5 & 22.5 & 22.5 \\
\hline Forage NDF, $\%$ of DM & 18.6 & 18.6 & 18.6 \\
\hline Ether extract, \% of DM & 4.5 & 4.5 & 4.5 \\
\hline $\mathrm{NE}_{\mathrm{L}},{ }^{7} \mathrm{Mcal} / \mathrm{kg}$ of DM & 1.63 & 1.63 & 1.63 \\
\hline \multicolumn{4}{|c|}{${ }^{1}$ Chemical analysis of diet samples composited for the experiment. } \\
\hline \multicolumn{4}{|c|}{${ }^{2}$ Contained $89.4,14.7$, and $49.9 \%, \mathrm{OM}, \mathrm{CP}$, and NDF, respectively. } \\
\hline \multicolumn{4}{|c|}{${ }^{3}$ Contained $92.3,10.2$, and $55.5 \% \mathrm{OM}, \mathrm{CP}$, and NDF, respectively. } \\
\hline \multicolumn{4}{|c|}{$\begin{array}{l}{ }^{4} \text { Composition (g/100 g of total FA): C14:0, 0.09; C16:0, 11.85; C16:1, 0.31; C18:0, 4.05; C18:1, 25.68; C18:2, } \\
51.59 \text {; C18:3, 6.11; and others, 0.32. }\end{array}$} \\
\hline \multicolumn{4}{|c|}{$\begin{array}{l}{ }^{5} \text { Supplied } 800,80,100,10,18,35.2,0.12,0.28,0.17 \text { and } 12 \mathrm{mg} / \mathrm{kg} \text { of diet } \mathrm{DM} \text { of calcium, phosphorus, magne- } \\
\text { sium, copper, manganese, zinc, cobalt, iodine, selenium, antioxidant, respectively, as well as vitamin A }(3,000 \\
\mathrm{IU} / \mathrm{kg}) \text {, vitamin D (800 IU } / \mathrm{kg}) \text {, and vitamin E }(6 \mathrm{IU} / \mathrm{kg}) \text {. }\end{array}$} \\
\hline \multicolumn{4}{|c|}{${ }^{6}$ Calculated by difference $100-(\% \mathrm{NDF}+\% \mathrm{CP}+\%$ fat $+\%$ ash $)$} \\
\hline${ }^{7}$ Based on tabular values & D & & \\
\hline
\end{tabular}

\section{Chemical Analyses}

Samples of TMR, yellow grease, alfalfa hay, and corn silage were composited over the experiment. The TMR, ingredient, orts (pooled by cow within period), and fecal (pooled by cow within period) samples were dried at $55^{\circ} \mathrm{C}$ in a forced-air oven for $48 \mathrm{~h}$ and ground to pass a 1-mm screen using a Wiley mill (Arthur H. Thomas Co., Philadelphia, PA). Chemical analyses were performed in duplicate (except 4 replications for FA). Samples were analyzed for CP (method 955.04), ether extract (method 920.39; AOAC International, 2002), and the $\mathrm{NDF}$ and ADF were sequentially analyzed (Van Soest et al., 1991) with heat-stable $\alpha$-amylase (Sigma A3306; Sigma-Aldrich, Steinheim, Germany) and sodium sulfite used in the NDF procedure. The ash content of samples was determined at $620^{\circ} \mathrm{C}$ for $8 \mathrm{~h}$. The NFC content was calculated as $100-(\% \mathrm{NDF}+\% \mathrm{CP}+$ $\%$ fat $+\%$ ash). Acid-insoluble ash was determined using the method described by Van Keulen and Young (1977). Fatty acid composition of the yellow grease was determined using a gas chromatograph (YounglingAcme 6000 series, Agilent 6890, Agilent Technologies, Seoul, South Korea) equipped with flame-ionization detector and capillary column $(50 \mathrm{~m} \times 0.25 \mathrm{~mm} \times 0.2$ $\mu \mathrm{m})$. About $0.5 \mathrm{~mL}$ of oil was converted to methyl ester using $3 \mathrm{~mL}$ of sodium methoxide $(1 M)$ in $7 \mathrm{~mL}$ of hexane before being injected into the gas chromatograph. The detector temperature was programmed at $260^{\circ} \mathrm{C}$ with flow rate of $0.8 \mathrm{~mL} / \mathrm{min}$. The oven temperature was set at $175^{\circ} \mathrm{C}$ and the injector temperature was set at $250^{\circ} \mathrm{C}$. Hydrogen was used as the carrier gas. The identification of the peaks was achieved from the retention times by comparison with standards (FAME Mix C4-C24, Supelco, Sigma-Aldrich, St. Louis, MO) analyzed under the same conditions. The FA composition of milk fat was analyzed using the method described by Loor et al. (2005) and Kargar et al. (2012). 


\section{Determination of PS, Sorting Activity, and Feeding Behavior}

On the last 5 consecutive days of each period, samples of TMR, AH, and orts were collected daily for determination of PS. The PS of these samples was measured in triplicate using the Penn State Particle Separator (PSPS) equipped with 3 sieves and a bottom pan (Lammers et al., 1996). After sieving, samples were placed in a forced air oven at $55^{\circ} \mathrm{C}$ to determine $\mathrm{DM}$ of each sieved fraction. Physically effective factor (pef) values were determined as the total proportion of DM retained on the 19 and $8 \mathrm{~mm}$ sieves (pef8; Lammers et al., 1996) or on the 19, 8 and 1.18 sieves (pef1.18; Kononoff, 2002; Table 2). The peNDF was calculated by multiplying pef 8 and pef 1.18 by the NDF content of the diet (DM basis) to obtain peNDF8 and peNDF1.18, respectively. The geometric mean particle length (GMPL) was calculated according to the ASAE (1995; method S424.1) procedure.

On the last 5 consecutive days of each period, sorting of particles was determined from the actual intake of each fraction compared with the predicted intake of the same fraction had the diet been consumed as formulated (Leonardi and Armentano, 2003). Sorting index was calculated for each fraction as the percentage of actual intake relative to the predicted intake. Values equal to $100 \%$ indicate no sorting, values $<100 \%$ indicate selective refusals (sorting against), and values $>100 \%$ indicate preferential consumption (sorting for).

On d 18 and 19 of each period, feed bunk contents for each animal were weighed and sampled at 2, 4, 6, and $24 \mathrm{~h}$ after the morning feeding to determine PS after feeding and cumulative DMI. These measurements were made to determine whether treatments affected

Table 2. Physical characteristics of the alfalfa hays used in the diets

\begin{tabular}{lccc}
\hline & \multicolumn{3}{c}{ Alfalfa hay } \\
\cline { 2 - 4 } Item $^{1}$ & Fine & Medium & Long \\
\hline DM retained on sieve, $\%$ & & & \\
$19.0 \mathrm{~mm}$ & 0.0 & 2.1 & 4.8 \\
$8.0 \mathrm{~mm}$ & 6.5 & 25.9 & 37.6 \\
$1.18 \mathrm{~mm}$ & 50.5 & 45.7 & 5.6 \\
$<1.18 \mathrm{~mm}$ & 42.9 & 26.2 & 16.9 \\
pef8 & 0.06 & 0.28 & 0.42 \\
pef1.18 & 0.57 & 0.73 & 0.83 \\
peNDF8, \% of DM & 2.8 & 12.1 & 18.3 \\
peNDF1.18, \% of DM & 24.6 & 31.8 & 35.9 \\
GMPL, mm & 2.1 & 3.6 & 5.0 \\
\hline
\end{tabular}

${ }^{1}$ pef8 and pef1.18 = physical effectiveness factor determined as the DM proportion of particles retained on 2 sieves $(19$ and $8 \mathrm{~mm}$ ) or 3 sieves $(19,8$, and $1.18 \mathrm{~mm})$, respectively, of the Penn State Particle Separator (Lammers et al., 1996; Kononoff, 2002); peNDF8, peNDF1.18 = physically effective NDF calculated as dietary NDF content (\% DM) multiplied by pef 8 and pef1.18, respectively; GMPL = geometric mean particle size as calculated by ASAE (1995; method S424.1). particle sorting and rate of feed intake after feed delivery. All samples were sieved using the PSPS and placed in a forced-air oven at $55^{\circ} \mathrm{C}$ to determine the $\mathrm{DM}$ of each sieved fraction as previously described.

\section{Chewing Activity}

On d 17 of each period, chewing activity was monitored visually for each cow over a 24 -h period. Eating and ruminating activities were noted at 5-min intervals, and each activity was assumed to persist for the entire 5-min interval (Colenbrander et al., 1991). A period of rumination was defined as at least 5 min of rumination occurring after at least 5 min without rumination. A meal was defined as at least one observation of eating activity occurring after at least 20 min without eating activity (Wangsness et al., 1976). The time spent eating, ruminating, and chewing (eating + ruminating) per kilogram of DMI and NDF intake, and number of meals per day, meal length (min), meal size ( $\mathrm{kg}$ of DM), and eating rate (total daily $\mathrm{DMI} /$ total eating time; $\mathrm{kg}$ of $\mathrm{DM} / \mathrm{min}$ ) were reported. The chews/bolus (chewing rate) were counted for 10 consecutive boluses for each cow during a randomly selected daytime and nighttime period for each cow.

\section{Statistical Analyses}

Data were analyzed using the mixed model procedure of SAS (Proc Mixed; SAS Institute, 2002) to account for effects of square, cow within square, and treatment. The treatment was considered a fixed effect; square, period and cow within square were considered random effects. Estimation method was REML and the degrees of freedom method was Kenward-Rogers. Data for particle distribution, pef, and peNDF of forages and diets were averaged by period and analyzed by including treatment as a fixed effect and period as a random effect. Linear and quadratic orthogonal contrasts were tested using the CONTRAST statement of SAS. Pearson correlation coefficients were estimated using the CORR procedure of SAS. Repeated measurements of cumulative consumption of DM and particles were analyzed by including a REPEATED model statement, as well as terms for time and interaction of treatment by time. Effects of the factors were declared significant at $P \leq 0.05$ unless otherwise noted and trends were discussed at $P \leq 0.10$.

\section{RESULTS}

\section{Particle Length and Physically Effective Fiber}

As intended, increasing the chop length of $\mathrm{AH}$ increased the proportion of particles retained on the top 
2 sieves of the PSPS and decreased the proportion of particles retained on the bottom sieve and the pan, causing large increases in pef8 and pef1.18 values, and peNDF (peNDF8, peNDF1.18) contents of AH (Table 2). Similarly, GMPL of AH increased linearly with increasing PS. Thus, incorporating AH of various PS in the diets resulted in greater proportions of 8- and 19$\mathrm{mm}$ particles and lower proportions of 1.18 - and $<1.18$ $\mathrm{mm}$ particles in the TMR (Table 3 ). The net effect of increasing the PS of alfalfa hay was a linear increase in dietary pef (pef8 and pef1.18), peNDF (peNDF8 and peNDF1.18), and GMPL.

\section{Intake and Digestibility}

Intakes of DM, OM, and peNDF1.18 were quadratically affected by the PS of AH, with highest intakes for the medium PS diet (Table 4). Intake of peNDF8 increased in a curvilinear manner, such that the highest intake was for the long PS diet. However, diet had no effect on nutrient digestibility.

\section{Particle Intake, Sorting Index, and Eating Behavior}

Cumulative DMI after feeding was similar across treatments, with cows consuming, on average, 23.4, 35.6 , and $46.4 \%$ of their daily DMI at 2, 4 and $6 \mathrm{~h}$ after feeding, respectively. The quadratic DMI response at $24 \mathrm{~h}$ after feeding indicates that the higher intake of cows fed the medium PS diet occurred later in the day (i.e., more than $6 \mathrm{~h}$ postfeeding). Dietary PS had no effect on sorting index (Table 5). Cows on all diets sorted against the $19-\mathrm{mm}$ particles (sorting index <100\%), favoring the other particles $(8,1.18$, and $<1.18 \mathrm{~mm}$ in length, indexes $>100 \%$ ). By examining the sorting index in relation to feed delivery, it was determined that by $4 \mathrm{~h}$ postfeeding, cumulative consumption of longer particles (i.e., 8 and $19 \mathrm{~mm}$ ) increased linearly with increasing PS, whereas the intake of shorter particles decreased linearly $(1.18 \mathrm{~mm})$ or tended (pan; $P$ $=0.10)$ to decrease with increasing PS. These patterns remained consistent throughout the remainder of the day.

\section{Chewing Activity}

Increasing dietary PS linearly increased eating time $(\mathrm{min} / \mathrm{d})$ and eating time adjusted for DMI but not eating time adjusted for NDF, indicating that the increase in eating time was partially a result of higher NDF intake (Table 6). Longer eating time associated with increased dietary PS corresponded to slower eating rate $(\mathrm{kg}$ of $\mathrm{DM} / \mathrm{min})$, but meal size ( $\mathrm{kg}$ of $\mathrm{DMI})$ and meal length $(\mathrm{min} / \mathrm{meal})$ were not affected. $\mathrm{Ru}-$ mination variables were generally unaffected by the change in PS, except daily rumination time $(\mathrm{min} / \mathrm{d})$, which responded quadratically, with the highest rumination time occurring for medium PS. The linear increase in eating time combined with the quadratic pattern of rumination time resulted in a trend for a quadratic $(P=0.06)$ increase $(P=0.09)$ in chewing time such that chewing time was highest for the medium PS, intermediate for long PS, and lowest for short PS. Chewing time adjusted for DMI ( $\mathrm{min} / \mathrm{kg}$ of DM) increased with DMI, but was similar when adjusted for NDF intake.

Table 3. Physical characteristics of diets containing alfalfa hay ${ }^{1}$ ranging in particle length

\begin{tabular}{lccc}
\hline & \multicolumn{2}{c}{ Diet } \\
\cline { 2 - 4 } Item $^{2}$ & Fine & Medium & Long \\
\hline DM retained on sieve, \% & & & \\
$19.0 \mathrm{~mm}$ & 3.6 & 5.1 & 5.7 \\
$8.0 \mathrm{~mm}$ & 14.2 & 20.1 & 46.4 \\
$1.18 \mathrm{~mm}$ & 52.2 & 49.0 & 24.2 \\
$<1.18$ & 29.9 & 25.8 & 0.29 \\
pef8 & 0.17 & 0.25 & 0.75 \\
pef1.18 & 0.70 & 0.74 & 9.4 \\
peNDF8, \% of DM & 5.7 & 8.1 & 24.4 \\
peNDF1.18, \% of DM & 22.5 & 23.9 & 3.9 \\
GMPL, mm & 3.00 & 3.5 & \\
\hline
\end{tabular}

${ }^{1}$ The fine-, medium-, and long-chopped alfalfa hays had, respectively, 0.0, 2.1, and 4.8\% of DM retained on the $19-\mathrm{mm}$ sieve; $6.5,25.9$, and $37.7 \%$ on the $8-\mathrm{mm}$ sieve; $50.5,45.7$, and $45.6 \%$ on the $1.18-\mathrm{mm}$ sieve; and 42.9 , 26.2 , and $16.9 \%$ of $\mathrm{DM}<1.18 \mathrm{~mm}$.

${ }^{2}$ pef8 and pef1.18 = physical effectiveness factor determined as the DM proportion of particles retained on 2 sieves (19 and $8 \mathrm{~mm}$ ) or 3 sieves $(19,8,1.18 \mathrm{~mm}$ ), respectively, of the Penn State Particle Separator (Lammers et al., 1996; Kononoff, 2002); peNDF8, peNDF1.18 = physically effective NDF calculated as dietary NDF content (\% DM) multiplied by pef8 and pef1.18, respectively; GMPL = geometric mean particle size as calculated by ASAE (1995; method S424.1). 
Table 4. Nutrient intake and total-tract digestibility for lactating dairy cows fed diets differing in alfalfa hay particle size ( $\mathrm{n}=9$ cows)

\begin{tabular}{|c|c|c|c|c|c|c|}
\hline \multirow[b]{2}{*}{ Item $^{1}$} & \multicolumn{3}{|c|}{ Diet } & \multirow[b]{2}{*}{ SEM } & \multicolumn{2}{|c|}{$P$-value } \\
\hline & Fine & Medium & Long & & Linear & Quadratic \\
\hline \multicolumn{7}{|l|}{ Intake, $\mathrm{kg} / \mathrm{d}$} \\
\hline DM & 24.7 & 25.4 & 23.7 & 0.43 & 0.13 & 0.04 \\
\hline $\mathrm{OM}$ & 22.4 & 23.1 & 21.3 & 0.44 & 0.12 & 0.04 \\
\hline NDF & 10.0 & 10.6 & 9.8 & 0.31 & 0.59 & 0.11 \\
\hline peNDF8 & 1.5 & 2.0 & 2.2 & 0.07 & $<0.01$ & $<0.01$ \\
\hline peNDF1.18 & 5.5 & 6.0 & 5.7 & 0.14 & 0.31 & $<0.01$ \\
\hline \multicolumn{7}{|l|}{ Digestibility, \% } \\
\hline $\mathrm{DM}$ & 66.4 & 68.9 & 69.4 & 2.1 & 0.33 & 0.71 \\
\hline $\mathrm{OM}$ & 68.3 & 70.7 & 71.4 & 1.99 & 0.28 & 0.74 \\
\hline $\mathrm{NDF}$ & 54.0 & 55.3 & 58.5 & 2.96 & 0.29 & 0.28 \\
\hline $\mathrm{ADF}$ & 54.3 & 55.3 & 56.2 & 1.63 & 0.22 & 0.75 \\
\hline $\mathrm{CP}$ & 68.0 & 70.1 & 71.5 & 1.99 & 0.23 & 0.88 \\
\hline Ether extract & 77.5 & 78.9 & 81.1 & 1.95 & 0.21 & 0.86 \\
\hline
\end{tabular}

\section{Milk Production and Composition}

Actual and 4\% FCM yields were quadratically affected by dietary PS, with highest production for the medium PS (Table 7). Milk fat percentage linearly increased with increasing PS, which led to a trend $(P$ $=0.08$ ) for increasing fat yield. Dietary PS did not affect milk protein percentage, but milk protein yield increased in a quadratic manner, with the highest yield for medium PS, intermediate yield for fine PS, and the lowest yield for long PS. Treatment had no effect on lactose yield or percentage. The fat:protein ratio increased linearly with increasing PS but remained $<1.0$ for all diets.

Increasing dietary PS had no effect on the proportion of short-, medium-, or long-chain FA in milk (Table 8). Degree of saturation as well as saturated:unsaturated FA were similar across treatments. Moreover, the total CLA content of milk FA and the amount of trans FA were not affected by the treatments, although a numerical decrease in total CLA was observed with increasing dietary PS.

\section{DISCUSSION}

There is a paucity of information on the effects of increasing the peNDF content of diets containing unsaturated fats. In our study, the peNDF content of the diets was increased by altering the PS of the $\mathrm{AH}$, which represented $24 \%$ of the dietary DM. Diets were high in NFC (42\%) and included $2 \%$ yellow grease as an unsaturated fat source, such that total dietary ether extract content was $4.5 \%$ (Table 1). Based on diet composition, a relatively low ruminal $\mathrm{pH}$ would have been expected, especially for the fine diet, although we did not measure ruminal $\mathrm{pH}$ directly in this study.

The differences in PS for the AH used in our study were chosen to represent the normal range in PS of $\mathrm{AH}$ used by commercial dairy farms. The differences in PS of the fine, medium, and long AH measured as GMPL and pef were lower than those reported by Teimouri Yansari et al. (2004), but Nasrollahi et al. (2012) showed that marginal increases in PS of AH can have significant effects on feeding behavior and ruminal $\mathrm{pH}$. Increasing the PS of the $\mathrm{AH}$ in our study increased the

Table 5. Sorting index for lactating dairy cows fed diets differing in alfalfa hay particle $\operatorname{size}^{1}(\mathrm{n}=9$ cows)

\begin{tabular}{lrrrrrrr}
\hline & \multicolumn{3}{c}{ Diet } & & \multicolumn{3}{c}{$P$-value } \\
\cline { 2 - 4 } \cline { 6 - 7 } Sieve & Fine & Medium & Long & & SEM & Linear & Quadratic \\
\hline $19 \mathrm{~mm}$ & 96.4 & 88.4 & 86.3 & 3.79 & 0.11 & 0.25 \\
$8 \mathrm{~mm}$ & 100.7 & 100.7 & 100.2 & & 0.32 & 0.26 & 0.41 \\
$1.18 \mathrm{~mm}$ & 100.4 & 97.9 & 101.1 & & 1.85 & 0.77 & 0.23 \\
$<1.18 \mathrm{~mm}$ & 100.7 & 101.3 & 101.7 & & 0.30 & 0.03 & 0.80 \\
\hline
\end{tabular}

${ }^{1}$ Sorting index was calculated as the percentage of actual intake relative to the predicted intake of each particle fraction. Values equal to $100 \%$ indicate no sorting, values < $100 \%$ indicate selective refusals (sorting against), and values $>100 \%$ indicate preferential consumption (sorting for). 
KAHYANI ET AL.

Table 6. Chewing activity of lactating dairy cows fed diets differing in alfalfa hay particle size ( $\mathrm{n}=9$ cows)

\begin{tabular}{|c|c|c|c|c|c|c|}
\hline \multirow[b]{2}{*}{ Item } & \multicolumn{3}{|c|}{ Diet } & \multirow[b]{2}{*}{ SEM } & \multicolumn{2}{|c|}{ Effect } \\
\hline & Fine & Medium & Long & & Linear & Quadratic \\
\hline \multicolumn{7}{|l|}{ Eating } \\
\hline $\min / \mathrm{d}$ & 259 & 273 & 288 & 9.06 & 0.03 & 0.95 \\
\hline $\min / \mathrm{kg}$ of $\mathrm{DM}$ & 10.7 & 10.8 & 12.3 & 0.43 & 0.01 & 0.28 \\
\hline $\mathrm{min} / \mathrm{kg}$ of $\mathrm{NDF}$ & 26.2 & 25.9 & 30.0 & 1.55 & 0.10 & 0.28 \\
\hline Meals, no./d & 14.2 & 14.0 & 13.5 & 0.78 & 0.55 & 0.90 \\
\hline Length, min/meal & 18.6 & 20.5 & 20.8 & 0.91 & 0.11 & 0.50 \\
\hline Eating rate, $\mathrm{kg}$ of $\mathrm{DM} / \mathrm{min}$ & 0.09 & 0.09 & 0.08 & 0.002 & 0.01 & 0.35 \\
\hline Meal size, $\mathrm{kg}$ of DM & 1.76 & 1.88 & 1.81 & 0.10 & 0.72 & 0.47 \\
\hline \multicolumn{7}{|l|}{ Ruminating } \\
\hline $\mathrm{min} / \mathrm{d}$ & 418 & 465 & 429 & 13.44 & 0.55 & 0.02 \\
\hline $\mathrm{min} / \mathrm{kg}$ of $\mathrm{DM}$ & 17.1 & 18.4 & 18.2 & 0.62 & 0.21 & 0.30 \\
\hline $\min / \mathrm{kg}$ of NDF & 42.2 & 44.3 & 44.4 & 1.79 & 0.40 & 0.66 \\
\hline Bouts, no./d & 11.4 & 11.4 & 11.9 & 0.46 & 0.50 & 0.70 \\
\hline Length, min/bout & 36.8 & 40.8 & 37.2 & 2.41 & 0.89 & 0.22 \\
\hline Chews, no./bolus & 71.1 & 75.6 & 72.7 & 2.40 & 0.66 & 0.26 \\
\hline \multicolumn{7}{|l|}{ Total chewing } \\
\hline $\min / \mathrm{d}$ & 677 & 738 & 718 & 16.16 & 0.09 & 0.06 \\
\hline $\mathrm{min} / \mathrm{kg}$ of $\mathrm{DM}$ & 27.6 & 29.3 & 30.5 & 0.82 & 0.02 & 0.84 \\
\hline $\min / \mathrm{kg}$ of NDF & 68.4 & 71.8 & 74.4 & 2.90 & 0.16 & 0.90 \\
\hline
\end{tabular}

Table 7. Milk production and composition for dairy cows fed diets differing in alfalfa hay particle size $(\mathrm{n}=$ 9 cows)

\begin{tabular}{|c|c|c|c|c|c|c|}
\hline \multirow[b]{2}{*}{ Item } & \multicolumn{3}{|c|}{ Diet } & \multirow[b]{2}{*}{ SEM } & \multicolumn{2}{|c|}{ Effect } \\
\hline & Fine & Medium & Long & & Linear & Quadratic \\
\hline Milk yield, $\mathrm{kg} / \mathrm{d}$ & 41.5 & 43.2 & 40.4 & 0.86 & 0.35 & 0.04 \\
\hline $4 \% \mathrm{FCM}, \mathrm{kg} / \mathrm{d}$ & 33.8 & 36.1 & 34.8 & 0.69 & 0.30 & 0.05 \\
\hline Fat yield, $\mathrm{kg} / \mathrm{d}$ & 1.14 & 1.24 & 1.23 & 0.03 & 0.08 & 0.25 \\
\hline Fat content, $\%$ & 2.77 & 2.89 & 3.08 & 0.08 & 0.02 & 0.78 \\
\hline Protein yield, $\mathrm{kg} / \mathrm{d}$ & 1.33 & 1.37 & 1.27 & 0.02 & 0.03 & $<0.01$ \\
\hline Protein content, ${ }^{1} \%$ & 3.23 & 3.21 & 3.18 & 0.03 & 0.36 & 0.97 \\
\hline Lactose, $\mathrm{kg} / \mathrm{d}$ & 2.39 & 2.49 & 2.30 & 0.06 & 0.33 & 0.10 \\
\hline Lactose content, \% & 5.76 & 5.75 & 5.71 & 0.05 & 0.46 & 0.75 \\
\hline Fat:protein & 0.85 & 0.90 & 0.97 & 0.02 & 0.01 & 0.79 \\
\hline
\end{tabular}

${ }^{1}$ True protein.

Table 8. Milk FA composition (\% of FA) for dairy cows fed diets differing in alfalfa hay particle size $(\mathrm{n}=9$ cows)

\begin{tabular}{|c|c|c|c|c|c|c|}
\hline \multirow[b]{2}{*}{ Item } & \multicolumn{3}{|c|}{ Diet } & \multirow[b]{2}{*}{ SEM } & \multicolumn{2}{|c|}{ Effect } \\
\hline & Fine & Medium & Long & & Linear & Quadratic \\
\hline \multicolumn{7}{|l|}{ Fatty acid } \\
\hline $\mathrm{C} 4$ to $\mathrm{C} 14$ & 32.06 & 32.47 & 32.00 & 1.90 & 0.98 & 0.85 \\
\hline C16:0 & 28.94 & 30.22 & 29.67 & 1.28 & 0.70 & 0.57 \\
\hline $\mathrm{C} 16: 1$ & 2.14 & 2.04 & 2.25 & 2.21 & 0.74 & 0.57 \\
\hline C18:0 & 7.69 & 7.68 & 7.02 & 0.46 & 0.34 & 0.57 \\
\hline C18:1 & 19.96 & 19.48 & 19.62 & 0.98 & 0.81 & 0.80 \\
\hline C18:1 trans & 1.69 & 1.68 & 1.40 & 0.15 & 0.21 & 0.46 \\
\hline $\mathrm{C} 18: 2$ & 2.21 & 2.15 & 1.97 & 0.22 & 0.47 & 0.83 \\
\hline $\mathrm{C} 18: 3$ & 0.08 & 0.08 & 0.15 & 0.03 & 0.22 & 0.53 \\
\hline $\mathrm{C} 20: 0$ & 0.19 & 0.63 & 0.38 & 0.26 & 0.64 & 0.32 \\
\hline $\mathrm{C} 22: 0$ & 0.11 & 0.13 & 0.10 & 0.04 & 0.78 & 0.63 \\
\hline Total conjugated linoleic acid & 0.27 & 0.23 & 0.21 & 0.03 & 0.20 & 0.88 \\
\hline Saturated FA & 70.90 & 72.64 & 71.30 & 1.65 & 0.87 & 0.46 \\
\hline Unsaturated FA & 29.09 & 27.35 & 28.70 & 1.63 & 0.85 & 0.47 \\
\hline Saturated:Unsaturated & 2.53 & 2.88 & 2.60 & 0.21 & 0.81 & 0.26 \\
\hline
\end{tabular}


dietary concentration of peNDF 8 by $42 \%$ from fine to medium, and an additional $16 \%$ from medium to long. However, peNDF1.18 was only increased by $6 \%$ from fine to medium, and a further $2 \%$ from medium to long.

The observed quadratic effects of dietary PS on nutrient intake were not expected, given that previous studies with corn silage (Kononoff et al., 2003) or AH (Teimouri Yansari et al., 2004) showed a linear decrease in DMI with increasing forage PS, whereas others (Grant et al., 1990; Nasrollahi et al., 2012) reported no effect of forage PS on nutrient intake. The filling effect of fiber particles is an important factor controlling DMI in high-producing dairy cows in mid lactation (Allen, 2000), and might have been a factor in our study given that the cows were, on average, between 88 and 151 DIM during the study. Greater nutrient intake of the medium diet compared with the fine diet, despite a higher filling due to increased PS, may have been due to improved rumen function (elevated ruminal $\mathrm{pH}$, increased reticuloruminal motility, greater rate of passage) caused by increased rumination and total chewing time. In contrast, the increased filling effect of the long PS diet, without a further increase in rumination and total chewing time, may have caused the lower DMI of the long versus medium diet.

The cumulative intake pattern of the cows postfeeding revealed that differences in DMI response to dietary PS occurred later in the day (i.e., after $6 \mathrm{~h}$ postfeeding). Similarly, for cows fed grass hays with varying PS, DMI was not affected during the first $8 \mathrm{~h}$ postfeeding (Maulfair et al., 2010). However, Kononoff et al. (2003) conducted similar measurements using corn silage and showed that increasing forage PS quadratically affected DMI in the first $8 \mathrm{~h}$ after feeding. Because rumen fill is low before feeding, we speculate that rumen fill caused by bulk density of the diet did not restrict feed intake in the first hours after feeding. Rather, the cow's appetite (energy demand) promoted intake immediately after feeding, and only when the rumen became full did rumen fill restrict feed intake.

One of the concerns associated with increased PS of forage is the potential for sorting; dairy cows are able to select against long particles (Zebeli et al., 2012). The net effect of sorting long particles can be a decrease in actual peNDF intake despite longer PS of the forage. However, with the moderate range in PS of the diets used in this study and the low proportion $(<5 \%$ of DM, Table 2) of long (19 mm) particles in all $3 \mathrm{AH}$, sorting of particles was minimal and not an important consideration.

Increased AH PS increased total eating time and eating time adjusted for DMI, reflecting the increased time it took cows to masticate the longer particles in the diets with higher peNDF content. It should be recog- nized, however, that chewing activity in this study was only recorded for a single 24 -h interval each period, and thus the repeatability of these observations within cow was not determined. However, the results are consistent with Nasrollahi et al. (2012), who also observed an increase in eating time with increased AH PS. In contrast to eating time, differences in rumination time with $\mathrm{AH}$ PS reflected the differences in DMI, as rumination time adjusted per intake was not affected by PS. Kononoff et al. (2003) also reported that DMI was an important driver of rumination time. Our study indicates that marginal increases in dietary PS increase eating time, but that mastication during eating may remove differences in PS of the ingesta and, therefore, negate the effects of dietary PS on rumination time. Bailey et al. (1990) showed that chopped AH particles $>4,750 \mu \mathrm{m}$ were reduced more during initial mastication than during rumination. It should be noted that harvest method and forage species can influence the outcome of forage PS; it has been shown that grass silage is more resistant to particle breakdown than alfalfa silage (Krause and Combs, 2003).

The quadratic effect of PS on milk production reflected the differences in DMI. Many other studies report no differences in milk production with increased dietary AH PS (Grant et al., 1990; Krause et al., 2002; Kononoff et al., 2003) or a trend for increased FCM yield due to increased milk fat percentage (Grant et al., 1990; Kononoff et al., 2003). The discrepancy between the present study and previous work may be explained in part by differences in DMI resulting from the use of diets high in NFC that were supplemented with unsaturated fat. Supplementation of unsaturated fat to the diet can alter the end products of fermentation (i.e., VFA and long-chain fatty acids), intraruminal stratification and reticular-ruminal motility (Palmquist, 1990; Reidelberger, 1994; Harvatine and Allen, 2006d), all of which can influence DMI.

Increased milk fat percentage with increasing $\mathrm{AH}$ PS, and the corresponding increase in fat:protein ratio, suggests a more favorable rumen environment with increasing dietary PS. We attribute the changes in milk fat percentage to increased ruminal $\mathrm{pH}$ as a result of the increase in total chewing time per kilogram of DMI, although we did not measure ruminal $\mathrm{pH}$ in this study. Increasing the dietary PS of diets supplemented with unsaturated fat might be an important consideration for preventing milk fat reduction because feeding high levels of unsaturated fats can lead to milk fat depression (Harvatine and Allen, 2006b). Although increasing AH PS has been shown to increase milk fat concentration (Grant et al., 1990; Teimouri Yansari et al., 2004), this is not always the case (Krause et al., 2002; Alamouti et al., 2009). Differences among studies might be attrib- 
uted to other factors such as level of NDF in the diets (29-36\% of DM), source of forages and preservation method (alfalfa or corn; hay or silage), and level of dietary unsaturated fat $(0-5 \%)$.

Despite the increase in milk fat content with increasing PS, milk fat percentage and fat:protein ratio were low for all treatments in this study, indicating milk fat depression (Table 7). Other studies that examined effects of forage PS reported milk fat concentrations considered normal for Holstein cows (i.e., >3.5\%) (Teimouri Yansari et al., 2004; Bhandari et al., 2008; Maulfair et al., 2010). The low milk fat content in our study was attributed to the use of high NFC diets that contained yellow grease. Unsaturated FA precursors can cause milk fat depression when ruminal $\mathrm{pH}$ is low because of incomplete biohydrogenation of PUFA to SFA (Bauman and Griinari, 2001; Harvatine and Allen, 2006c).

Despite a significant change in milk fat percentage with increasing PS of diets, the FA composition of milk fat was similar across treatments. The effects of forage PS on milk fat composition remain inconsistent among studies. In agreement with our findings, Onetti et al. (2003) and Soita et al. (2005) observed no effect of corn silage PS on FA composition of milk, indicating similar biohydrogenation potential of diets. However, Onetti et al. (2004) showed a significant decrease in C18:0 and trans-10 C18:1 and increases in C18:2 and C18:3 with increasing alfalfa hay PS in a diet supplemented with $2 \%$ tallow. They suggested that selective sorting against long-stem hay reduced ruminal $\mathrm{pH}$ and increased the production of trans FA. It appears that in our study, because no difference in sorting activity occurred among diets, biohydrogenation was similar for all diets.

\section{CONCLUSIONS}

Increasing PS of the $\mathrm{AH}$ used in diets containing $2 \%$ added unsaturated fat linearly increased dietary peNDF content and its intake without affecting sorting of the diet. Increased peNDF intake increased daily eating time and total chewing time per DMI and increased milk fat percentage and fat:protein ratio. Moreover, increasing PS quadratically affected DMI, with cows receiving medium $\mathrm{AH}$ having the highest DMI. Milk production, FCM, and protein yield also responded quadratically. Milk fat and fat:protein ratio were low for all treatments due to the high concentration of NFC ( $42 \%$ of DM) and the addition of yellow grease to the diets. However, the FA composition of milk was similar across treatments. Results indicate that increasing the PS of high-concentrate diets supplemented with unsaturated fat to increase peNDF intake can be beneficial to chewing activity and milk fat production. Under the conditions of this study, a diet with medium $\mathrm{AH}$ PS supplying $23.9 \%$ of dietary peNDF1.18 (DM basis) optimized DMI and milk production.

\section{ACKNOWLEDGMENTS}

The authors thank the staff of the Dairy Research and Teaching Unit of Isfahan University of Technology for the technical assistance. We also thank Richard A. Erdman (University of Maryland, College Park), and $\mathrm{PhD}$ students S. Kargar, M. Mirzaee, E. Ghasemi, and F. Hashemzadeh-Cigari (Isfahan University of Technology, Iran) for their technical assistance. Also, we thank the Fat and Oil Laboratory of the Center of Agri-Food Research, Institute of Standards and Industrial Research (Karaj, Iran), for fatty acid analysis.

\section{REFERENCES}

Alamouti, A. A., M. Alikhani, G. R. Ghorbani, and Q. Zebeli. 2009 Effects of inclusion of neutral detergent soluble fibre sources in diets varying in forage particle size on feed intake, digestive processes, and performance of mid-lactation Holstein cows. Anim. Feed Sci. Technol. 154:9-23.

Allen, M. S. 2000. Effects of diet on short-term regulation of feed intake by lactating dairy cattle. J. Dairy Sci. 83:1598-1624.

AOAC International. 2002. Official Methods of Analysis. Vol. 1. 17th ed. AOAC International, Arlington, VA.

ASAE (American Society of Agricultural Engineers). 1995. Method of determining and expressing fineness of feed material by sieving. Page 461 in ASAE Standards 1995. ASAE, St. Joseph, MI.

Bailey, A. T., R. A. Erdmann, L. W. Smith, and B. K. Sharma. 1990. Particle size reduction during initial mastication of forages by dairy cattle. J. Anim. Sci. 68:2084-2094.

Bauman, D. E., and J. M. Griinari. 2001. Regulation and nutritional manipulation of milk fat: Low-fat milk syndrome. Livest. Prod. Sci. 70:15-29.

Bhandari, S. K., S. Li, K. H. Ominski, K. M. Wittenberg, and J. C. Plaizier. 2008. Effects of the chop lengths of alfalfa silage and oat silage on feed intake, milk production, feeding behavior, and rumen fermentation of dairy cows. J. Dairy Sci. 91:1942-1958.

Colenbrander, V. F., C. H. Noller, and R. J. Grant. 1991. Effect of fiber content and particle size of alfalfa silage on performance and chewing behavior. J. Dairy Sci. 74:2681-2690.

Coomer, J. C., H. E. Amos, C. C. Williams, and J. G. Wheeler. 1993. Response of early lactation cows to fat supplementation in diets with different nonstructural carbohydrate concentrations. J. Dairy Sci. 76:3747-3754.

Fox, D. G., T. P. Tylutki, K. J. Czymmek, C. N. Rasmussen, and V. M. Durbal. 2000. Development and application of the Cornell University nutrient management planning system. Pages 167-179 in Proc. Cornell Nutr. Conf. Feed Manuf., Rochester, NY. Cornell Univ., Ithaca, NY.

Grant, R. J., V. F. Colenbrander, and D. R. Mertens. 1990. Milk fat depression in dairy cows: Role of particle size of alfalfa hay. J. Dairy Sci. 73:1823-1833.

Grant, R. J., and S. J. Weidner. 1992. Effect of fat from whole soybeans on performance of dairy cows fed rations differing in fiber level and particle size. J. Dairy Sci. 75:2742-2751.

Harvatine, K. J., and M. S. Allen. 2006a. Effects of fatty acid supplements on feed intake, and feeding and chewing behavior of lactating dairy cows. J. Dairy Sci. 89:1104-1112.

Harvatine, K. J., and M. S. Allen. 2006b. Effects of fatty acid supplements on milk yield and energy balance of lactating dairy cows. J. Dairy Sci. 89:1081-1091. 
Harvatine, K. J., and M. S. Allen. 2006c. Effects of fatty acid supplements on ruminal and total tract nutrient digestion in lactating dairy cows. J. Dairy Sci. 89:1092-1103.

Harvatine, K. J., and M. S. Allen. 2006d. Fat supplements affect fractional rates of ruminal fatty acid biohydrogenation and passage in dairy cows. J. Nutr. 136:677-685.

Iranian Council of Animal Care. 1995. Guide to the Care and Use of Experimental Animals. Vol. 1. Isfahan University of Technology, Isfahan, Iran.

Jenkins, T. C., J. A. Bertrand, and W. C. Bridges Jr. 1998. Interactions of tallow and hay particle size on yield and composition of milk from lactating Holstein cows. J. Dairy Sci. 81:1396-1402.

Kargar, S., G. R. Ghorbani, M. Alikhani, M. Khorvash, L. Rashidi, and D. J. Schingoethe. 2012. Lactational performance and milk fatty acid profile of Holstein cows in response to dietary fat supplements and forage:concentrate ratio. Livest. Sci. 150:274-283.

Kononoff, P. J. 2002. The effect of ration particle size on dairy cows in early lactation. PhD Thesis. The Pennsylvania State University, University Park.

Kononoff, P. J., A. J. Heinrichs, and H. A. Lehman. 2003. The effect of corn silage particle size on eating behavior, chewing activities, and rumen fermentation in lactating dairy cows. J. Dairy Sci. $86: 3343-3353$

Krause, K. M., and D. K. Combs. 2003. Effects of forage particle size, forage source, and grain fermentability on performance and ruminal pH in midlactation cows. J. Dairy Sci. 86:1382-1397.

Krause, K. M., D. K. Combs, and K. A. Beauchemin. 2002. Effects of forage, particle size, and grain fermentability in midlactation cows. I. Milk production and diet digestibility. J. Dairy Sci. 85:19361946.

Lammers, B. P., D. R. Buckmaster, and A. J. Heinrichs. 1996. A simple method for the analysis of particle sizes of forages and total mixed rations. J. Dairy Sci. 79:922-928.

Leonardi, C., and L. E. Armentano. 2003. Effect of quantity, quality, and length of alfalfa hay on selective consumption by dairy cows. J. Dairy Sci. 86:557-564.

Loor, J. J., A. Ferlay, A. Ollier, M. Doreau, and Y. Chilliard. 2005. Relationship among trans and conjugated fatty acids and bovine milk fat yield due to dietary concentrate and linseed oil. J. Dairy Sci. $88: 726-740$

Maulfair, D. D., G. I. Zanton, M. Fustini, and A. J. Heinrichs. 2010 Effect of feed sorting on chewing behavior, production, and rumen fermentation in lactating dairy cows. J. Dairy Sci. 93:4791-4803.

Mertens, D. R. 1997. Creating a system for meeting the fiber requirements of dairy cows. J. Dairy Sci. 80:1463-1481.

Nasrollahi, S. M., M. Khorvash, G. R. Ghorbani, A. Teimouri-Yansari, A. Zali, and Q. Zebeli. 2012. Grain fermentability and marginal changes in forage particle size modulated digestive processes, and nutrient intake in dairy cows. Animal 6:1237-1245.

Onetti, S. G., S. M. Reynal, and R. R. Grummer. 2004. Effect of alfalfa forage preservation method and particle length on performance of dairy cows fed corn silage-based diets and tallow. J. Dairy Sci. $87: 652-664$.

Onetti, S. G., R. D. Shaver, S. J. Bertics, and R. R. Grummer. 2003. Influence of corn silage particle length on the performance of lactating dairy cows fed supplemental tallow. J. Dairy Sci. 86:29492957.

Palmquist, D. L. 1990. Using fat strategically in dairy cattle rations. Proc. Int. Anim. Nutr. Symp. Natl. Renderer's Assoc., Brussels, Belgium.

Reidelberger, R. D. 1994. Cholecystokinin and control of food intake. J. Nutr. 124:1327S-1333S.

SAS Institute. 2002. SAS User's Guide: Statistics. Version 9.1. SAS Institute Inc., Cary, NC

Soita, H. W., M. Fehr, D. A. Christensen, and T. Mutsvangwa. 2005. Effects of corn silage particle length and forage:concentrate ratio on milk fatty acid composition in dairy cows fed supplemental flaxseed. J. Dairy Sci. 88:2813-2819.

Teimouri Yansari, A., R. Valizadeh, A. Naserian, D. A. Christensen, P. Yu, and F. E. Shahroodi. 2004. Effects of alfalfa particle size and specific gravity on chewing activity, digestibility, and performance of Holstein dairy cows. J. Dairy Sci. 87:3912-3924.

Van Keulen, V., and B. H. Young. 1977. Evaluation of acid-insoluble ash as natural marker in ruminant digestibility studies. J. Anim. Sci. 26:119-135.

Van Soest, P. J., J. B. Robertson, and B. A. Lewis. 1991. Methods for dietary fiber, neutral detergent fiber, and nonstarch polysaccharides in relation to animal nutrition. J. Dairy Sci. 74:3583-3597.

Wangsness, P. J., L. E. Chase, A. D. Peterson, T. G. Hartsock, D. J. Kellmel, and B. R. Baumgardt. 1976. System for monitoring feeding behavior of sheep. J. Anim. Sci. 42:1544-1549.

Yang, W. Z., and K. A. Beauchemin. 2007. Altering physically effective fiber intake through forage proportion and particle length: Chewing and ruminal pH. J. Dairy Sci. 90:2826-2838.

Zebeli, Q., J. R. Aschenbach, M. Tafaj, J. Boguhn, B. N. Ametaj, and W. Drochner. 2012. Invited review: Role of physically effective fiber and estimation of dietary fiber adequacy in high-producing dairy cattle. J. Dairy Sci. 95:1041-1056.

Zebeli, Q., M. Tafaj, I. Weber, J. Dijkstra, H. Steingass, and W. Drochner. 2007. Effects of varying dietary forage particle size in two concentrate levels on chewing activity, ruminal mat characteristics and passage in dairy cows. J. Dairy Sci. 90:1929-1942. 